Environment Conservation Journal 14(3)73-78, 2013

ISSN 0972-3099 (Print) 2278-5124 (Online)

Abstracted and Indexed

\title{
Training needs of rural women regarding household energy saving practices through appropriate use of electrical appliances
}

\author{
Ravneet Kaur and Kanwaljit Kaur
}

Received: 27.10 .2013

Revised: 15.11.2013

Accepted: 29.11.2013

\begin{abstract}
The study was conducted in four blocks of Ludhiana district of Punjab state. The data were collected from 200 rural women with the help of interview schedule. A checklist of different household energy saving practices for use of electrical appliances was prepared by consulting the literature and subject matter specialists of Department of Family Resource Management, PAU, Ludhiana. Training needs of household energy saving practices through appropriate use of electrical appliances were analyzed by administrating the knowledge test. On basis of respondent's knowledge scores, Training Needs Quotient (TNQ) values were calculated and accordingly training needs intensity (T N I) was divided in to three categories i.e. low, medium, and high. Higher side T N I value indicate that respondent need training in that particular area. Overall respondents had medium training need intensity regarding household energy saving practices through appropriate use of electrical appliances. Education and mass media exposure of rural women had negative and significant relationship with training needs intensity. Positive and significant relationship was observed between age and training needs intensity. There is need to provide the training among rural women in the sub- areas of energy saving practices through appropriate use of electrical appliances in which they had high and medium training needs intensity. Mass media had significant relationship with training needs, so it is suggested that mass media planners should include more programmes and articles regarding these energy saving practices through appropriate use of electrical appliances.
\end{abstract}

Keyword: Rural women, household energy saving practices, training needs intensity (TNI), training needs quotient (TNQ)

\section{Introduction}

Energy is a basic requirement for economic development in almost all major sectors of Indian economy-agriculture, industry, transport, commercial and residential (domestic). Consequently, consumption of energy in different forms has been steadily rising all over the country and more so states like Punjab have maintained a steady growth pattern in the past and the trend is likely to continue in future as well. This has increased the dependence of the state on fossil fuels and electricity. The past three decades have seen a significant evolution in the science, practices and impact of energy efficiency. Energy efficiency has gradually emerged from being an advocacy subject to a powerful, cost-effective, and environmentfriendly policy tool to narrow the widening supplydemand gap faced by the Nation today. As per the

\section{Author's Address}

Department of Home Science Extension \& Communication Management, College of Home Science, Punjab Agricultural University, Ludhiana

Email: kanwaljithsee@pau.edu

energy conservation programs, if designed and executed properly, can obviate the need for additional 25,000 MW generation capacities. Energy conservation potential for the economy as a whole has been assessed as 23 per cent with maximum potential in Industrial and Agricultural Sectors (Punjab Energy Development Agency 2012). In order to cope up household energy crises, it is very important to adopt the household energysaving technologies at faster speed. The relevant technical know-how should be imparted to the general public, especially rural women because they are deprived of educational awareness regarding energy saving practices. The more energy efficient electrical appliance is the less its costs to run. So the present study has been planned with following objectives:

1. To assess the training needs intensity of rural women regarding household energy saving practices through appropriate use of electrical appliances

Copyright by ASEA

All rights of reproduction in any form reserved 
2. To study the relationship between the sociopersonal characteristics of rural women and their training needs.

\section{Material and methods}

The study was conducted in four blocks i.e. Sidhwan Bet, Sudhar, Jagraon and Ludhiana-I of Ludhiana district of Punjab State.Two villages from each selected block were further selected randomly. Total eight villages were selected for the study. A sample of 200 rural women within age group of 2040 year was drawn randomly by selecting 25 rural women from each selected village. Data were collected personally from the respondents with the help of interview schedule.

\section{Operationalization of concepts}

Household Energy Saving Practices: It was operationalized as scientific information, material, technical methods and process that require art of systematic use of electrical appliances for saving the electricity at household level. A checklist of household energy saving practices for use of electrical appliances was prepared by consulting the literature and Subject Matter Specialists from Family Resource Management.

Training Need:It referred to the gap between the expected knowledge (what out to be) and the existing knowledge (what is) of the rural women regarding household energy saving practices.Training need of the rural women was measured in terms of Training Need Quotient (TNQ) obtained for a set of questions/statements about household energy saving practices by the respondents. The arbitrary scores of ' 1 " and ' 0 ' were assigned to correct and incorrect responses respectively. The score obtained by each rural woman were summed up for all the statements. Similarly, the total score for each statement was worked out in the same way. Then the average score was calculated with the following formula:

$$
\begin{aligned}
& \text { Average knowledge score(for each statement })=\frac{\text { Total Score }}{\text { No.of respondent }} \\
& \text { Average knowledge score(for each respondent) }=\frac{\text { Total Score }}{\text { No.of statement }}
\end{aligned}
$$

TNQ was worked out for each respondent/specified practice and its sub items:

TNQ = 1- Average knowledge score
Where,

TNQ = Training Need Quotient of the respondent in particular practice and its sub items

$1=$ It represents the expected knowledge level score

The training Need Intensity (TNI) was worked out on the basis of Training Need Quotient (TNQ) scores. By using cumulative cube root frequency method, three categories were made and training need intensity was judged as 'Low', 'Medium' and 'High' with TNQ score ranges of $0-0.49,0.49-0.65$ and $0.65 \&$ above respectively.

\section{Results and Discussion}

Results have been presented under the following sub headings:

\section{Level of training needs intensity in household} energy saving practices through appropriate use of electrical appliances:Training Needs of rural women were measured in terms of TNQ scores. From TNQ score range, three categories for training needs intensity (TNI) of the respondents were made viz-'Low' (0-0.49), Medium (0.490.65), High (0.65\&above) (Fig. 1).On the scrutiny of distribution of responses, it was observed that 56 per cent of the respondents had 'high' training needs intensity, 39 per cent had 'medium' training needs intensity and the remaining 5 per cent had 'low' training needs intensity. . These results are supported by studies carried out by Malhotra (1996), Singh (1999), Singh (1997), Manshahia (2004) and Kaur (2002).

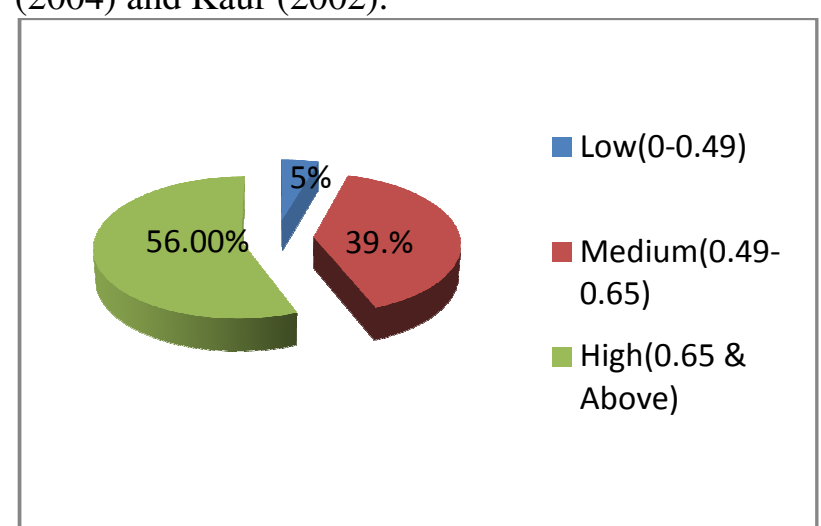

Fig 1 Distribution of respondents according to level of training needs in household energy saving practices through appropriate use of electrical appliances 
2. Training needs intensity in household energy saving practices through appropriate use of electrical appliances: It is fair to say that our everyday life would be completely different if someone had not invented refrigerator, microwave oven, iron, lights, fans and washing machine etc. Due to frequent use of these appliances we have to pay big amount of electricity bills. We can save the money if we follow the energy saving techniques while using these electrical appliances. So in this context training needs of rural women were studied under following electrical appliances.

2.1. Refrigerator: Today refrigerator has become basic necessity of every house in rural as well as urban areas. We preserve most of food items in refrigerators. There are different types of refrigerators in market like double and single door refrigerator. People preferred advanced technology equipment. There is a need to educate people some time advance technology consumes more electricity which is very precious source of energy for the country. Data (Table 1) regarding energy saving techniques related to refrigerator revealed that items related to disadvantages of double door refrigerator had high training needs intensity with training need quotient value 0.78 . Whereas medium training need intensity was observed for overloading of shelves item of refrigerator with training need quotient value 0.50 .Respondents had low training need intensity in statements i.e. 'Covered food in refrigerator consumes less energy' and 'to save fuel energy refrigerated food should be kept at room temperature prior to cooking' with TNQ values of 0.31 and 0.14 respectively.

Table 1: Distribution of respondents according to training needs intensity in household energy saving practices through appropriate use of electrical appliances

\begin{tabular}{|c|c|c|}
\hline Energy Saving Electrical Appliances/ Technologies & Training Need Quotient & Training Need Intensity \\
\hline 1 Refrigerators & & \\
\hline (i) Double door refrigerator consumes more energy & 0.78 & $\mathrm{H}$ \\
\hline (ii) Single door refrigerator consumes less energy & 0.22 & $\mathrm{~L}$ \\
\hline $\begin{array}{l}\text { (iii) Defrosting is required for the proper working of } \\
\text { freezer }\end{array}$ & 0.59 & M \\
\hline (iv) Covered food in refrigerator consumes less energy & 0.31 & $\mathrm{~L}$ \\
\hline (v) Overloading of shelves consume more electricity & 0.50 & M \\
\hline (vi) Overloading of shelves consume same electricity & 0.50 & M \\
\hline $\begin{array}{l}\text { (vii) To save fuel energy refrigerated food should be kept } \\
\text { at room temperature prior to cooking }\end{array}$ & 0.14 & $\mathrm{~L}$ \\
\hline 2. Microwave oven & & \\
\hline (i) Knowledge related microwave oven & 0.90 & $\mathrm{H}$ \\
\hline (ii) Microwave saves fuel energy & 0.90 & $\mathrm{H}$ \\
\hline $\begin{array}{l}\text { (iii) Microwave saves } 50 \% \text { energy as compare to } \\
\text { conventional gas }\end{array}$ & 0.94 & $\mathrm{H}$ \\
\hline $\begin{array}{l}\text { (iv) Opening microwave while it is running wastes } \\
\text { energy }\end{array}$ & 0.90 & $\mathrm{H}$ \\
\hline 3. Grinding & & \\
\hline (i) Wet grinding of spices consume more energy & 0.60 & M \\
\hline $\begin{array}{l}\text { (ii) Dry grinding for making vegetables curry } \\
\text { consumes more energy }\end{array}$ & 0.71 & $\mathrm{H}$ \\
\hline 4. Iron & & \\
\hline (i) While ironing, wet clothes consume more electricity & 0.13 & $\mathrm{~L}$ \\
\hline (ii) While ironing, dry clothes consume less electricity & 0.87 & $\mathrm{H}$ \\
\hline $\begin{array}{l}\text { iii) Automatic temperature cut-off iron is more energy } \\
\text { efficient than non-automatic iron }\end{array}$ & 0.36 & $\mathrm{~L}$ \\
\hline
\end{tabular}




\section{Lights}

(i) Slim tube rod is more energy efficient

\begin{tabular}{l|l}
0.80 & $\mathrm{H}$ \\
0.22 & $\mathrm{~L}$ \\
0.10 & $\mathrm{~L}$ \\
0.80 & $\mathrm{H}$ \\
0.63 & $\mathrm{M}$ \\
0.46 & $\mathrm{~L}$ \\
0.66 & $\mathrm{M}$ \\
0.56 & $\mathrm{M}$
\end{tabular}

$\mathrm{H}$

(ii) CFL bulb consumes less energy as compared to ordinary bulb

(iii) Tube rod consumes less energy than ordinary bulbs

6. Fans

(i) Modern regulator of the ceiling fan is more energy efficient than the conventional electrical regulators

(ii) Installation of exhaust fans at a higher elevation than ceiling fan effects the energy consumption

(iii) Use of regulator of ceiling fans saves energy

\section{Washing machine}

(i) Use of dryers in washing machine consumes more energy

(ii) Half loaded washing machines while washing clothes, wastes energy

\section{Miscellaneous}

(i) Length of wire of electrical appliances effect the energy consumption

(ii) Knowledge regarding significance of energy stars on electrical appliances

(iii) Less stars indicate more consumption

(iv) More stars indicate more consumption

(v) Using remote for switching off electrical appliances wastes electricity

(vi) Plugged in battery charger of laptop, cell phone etc. are inefficient and draw power

(vii) Leak proof AC rooms consume less power

viii) Computer set on sleep mode wastes the energy

(ix) Use of extension boards consumes more energy

(x) Indicators on switch boards waste electricity

(xi) ISI marked appliances save more energy

\section{Microwave oven}

Microwave oven is not very popular in rural area that's why only 10 per cent of respondents had knowledge. All respondents who had knowledge of microwave oven expressed high training need intensity in all sub items of microwave .TNQ values of all items were also 0.90 and above.

\subsection{Grinding}

Training need intensity was observed medium for grinding techniques of making spices. Whereas high for grinding techniques of making vegetables curry with 0.71 TNQ value.

\subsection{Iron}

For ironing the wet clothes and use of automatic temperature cut-off iron, rural women had low training needs intensity. While ironing the dry

clothes rural women had high training needs intensity with TNQ value 0.87 .

\subsection{Lights}

The use of ordinary bulbs consumes lot of electricity. Respondents had low training need intensity regarding knowledge of CFL bulb and tube rod. But high training need intensity was observed for use of energy efficient slim tube rod with TNQ value 0.80 .

\subsection{Fans}

TNQ value 0.46 in Table 1 indicated that respondents know that use of regulator of ceiling fan saves energy. Whereas high training need intensity was seen for conventional versus modern electrical regulator because they did not know 
modern regulator consumes less energy.Fitting of exhaust fan higher than ceiling fan level statement got the medium training needs intensity with TNQ value 0.63 .

\subsection{Washing machine}

Rural women had medium training needs intensity in energy efficient machine washing practices i.e. use of dryers and loading of washing machine.

\subsection{Miscellaneous}

Training needs intensity was assessed in miscellaneous energy saving electrical appliances/practices like effect of length of electrical appliances, number of energy stars on appliances, plugged in charger, use of extension board and ISI marked appliances. Respondents had high training need intensity for knowledge regarding switching off appliances with remote, significance of energy stars on electrical appliances, ISI marked appliances, computer set on sleep mode and effect of length of wire with TNQ values 0.92 , $0.82,0.79,0.74$ and 0.73 respectively. Low training need intensity was observed for plugged in battery charger, leak proof A.C room, use of extension board and indicator on switch board.

\section{Relationship between socio-personal characteristics and training needs of respondents:The relationship between the selected socio-personal characteristic of the respondents and their training needs was worked out with the help of coefficient of correlation the results so obtained have been presented in Table 2.}

Table2 Relationship between socio-personal characteristics and training need of respondents $(n=200)$

\begin{tabular}{|l|l|}
\hline Socio-personal characteristics & r-value \\
\hline Age & $0.021^{*}$ \\
\hline Education & $-0.2718^{* *}$ \\
\hline Family Income & $0.048 \mathrm{NS}$ \\
\hline Family size & $-0.028 \mathrm{NS}$ \\
\hline Extension contacts & $0.009 \mathrm{NS}$ \\
\hline Mass media exposure & $-0.310^{* *}$ \\
\hline
\end{tabular}

** Significant at $1 \%$ level

The age of the rural women was found to be positive and significantly correlated with training needs. It means that the age of respondent had high impact on training need intensity. These findings are in line with the findings of Singh (1997) who reported relationship between these two variables. However, the finding of Kaur (2002) was the contrary. The data given in the Table 2 indicated that the education of respondents was negatively and significantly correlated with training needs. In other words, as the educational level of rural women increased, their need for training decreased. This may be due to the fact that education enriched the mental horizons and added to the knowledge of the respondents and hence they required less training. Similar type of relationship was also found between these two variables by Singh (1997), Kaur (2002) and Manshahia (2004) who reported that education of the farmers/farm women was negatively and significantly correlated with their training needs. The family income of respondents was non-significant relationship with training needs of the rural women. In other words family income had no significant impact on the knowledge level of the rural women regarding household energy saving technologies. The correlation co-efficient between the family size and training needs was negative and non-significant. Whereas with extension contacts it 


\section{Kaur and Kaur}

was not correlated. These findings are not in line with Singh (1997) and Singh (1999) who reported that the extension contacts of farmers had negative and significant correlation with the training needs. The mass media exposure and training need intensity of the rural women was negatively and significantly correlated. It could be concluded that with increase in mass media exposure of the respondents, their training needs intensity decreased and vice-versa. This may be due to the fact that the rural women learn more with more exposure to mass media. These findings are supported by Singh (1994), Singh (1997) Singh (1999) and Manshahia (2004) who reported that mass media exposure was negatively and significantly correlated with the training needs of the farmers.

\section{Conclusion}

There is need to provide the training among rural women in energy saving practices through appropriate use of electrical appliances which they had high and medium training needs intensity. Education and mass media exposure of rural women had negative and significant relationship with training needs intensity. So its suggested that mass media planners should include more programmes and articles regarding these household energy saving practices through appropriate use of electrical appliances .

\section{References}

Kaur, B. 2002. Training needs of rural women engaged in cotton processing in the cotton belt of Punjab.M.Sc thesis, Punjab Agricultural University Ludhiana, India

Malthora, S. 1996. Training needs of okhra growers in Pakhowal block of Ludhiana district. M.S.c. thesis, Punjab Agricultural University Ludhiana, India.

Manshahia, R. S. 2004. Training needs and problems of fish farmers of Punjab.M.S.c. thesis, Punjab Agricultural University Ludhiana, India.

Punjab Energy Development Agency 2012. Retrieved fromhttp://peda.gov.in/eng/index.html.

Singh, J. 1997. Training needs of farmers regarding cottonwheat rotation in Bathinda district of Punjab. M.Sc. thesis, Punjab Agricultural University Ludhiana, India.

Singh, M. 1994. Training need as of fruit growers in Sangrur district of Punjab. M.Sc. Thesis, Punjab Agricultural University, Ludhiana, India.

Singh, S. 1999. Training needs of vegetable growers of Malerkotla tehsil of Sangrur district of Punjab.M.Sc.Thesis, Punjab Agricultural University, Ludhiana, India. 